\title{
Is Humor Advertising Always Effective? Parameters for Effective Use of Humor in Advertising
}

\author{
Aneta Djambaska \\ School of Business Economics and Management, University American College Skopje \\ U1. Treta Makedonska Brigada br.60, Skopje, Macedonia \\ E-mail: adzambaska@gmail.com
}

Ilijana Petrovska

School of Business Economics and Management, University American College Skopje U1. Treta Makedonska Brigada br.60, Skopje, Macedonia

E-mail: petrovska@uacs.edu.mk

Elena Bundalevska

School of Business Economics and Management, University American College Skopje

U1. Treta Makedonska Brigada br.60, Skopje, Macedonia

E-mail: bundalevska@uacs.edu.mk

Received: Oct. 12, 2015

doi:10.5296/jmr.v8i1.8419
Accepted: Nov. 10, $2015 \quad$ Published: January 1,2016

URL: http://dx.doi.org/10.5296/jmr.v8i1.8419

\begin{abstract}
The aim of this research is humor consumption and its extensive use in today's advertising. One of the most prominent features of humor is its convictive nature. A humorous context may increase liking for the source at the same time creating a positive mood. Humor does serve to make the audience laugh, make the viewers happy and create positive mood. In general, humor itself has a permanent presence and a specific role in advertising. However, it should be underlined that humor should be used carefully in advertisements; otherwise it may result in resistance. Using humor is regarded as a win-win situation. While in some cases humor usage depends on the product or brand advertised. In some cases humor is considered not appropriate if attached with some products and particular occasions.
\end{abstract}


Results show correlation effect and in fact humor related Ads found as much more effective than those without humor and this effect is apparent, when it comes to highly complex and sophisticated humor. Also the effect of humor is influenced by the type of product advertised. The implications of these findings for the practice of Advertising are discussed in following pages.

Keywords: Humor, Effects of humor, Humor relatedness, Humor complexity, Product types. 


\section{Introduction}

Humor may serve as a reward for audience for listening (Sternthal and Craig, 1973). Humorous content of the message may content persuasive effect, increase message linking and create positive mood. Humor is widely present in every culture. There is no culture in today world that doesn't possess a sense of humor. It is found everywhere - in movie industry, television, in books and newspapers, in our conversations, and in graffiti (Berger, 1987). Humor is Advertisement feature that would like to put people in a good mood and has a permanent role in advertising (Kuilenburg et al., 2011).

Use of humor in advertising is a complex topic (Zinkhan and Johnson, 1994). Even 55\% of executives believe that humor is superior compared with non-humor Advertising (Weinberger et. al, 1995). In general, humor is powerful in attracting consumers' attention and creates a positive effect. According to Dong-Hun (2009) the use of humor in advertising has been widely increased. In reality things not always go that way and are not strictly predictable. Humor does not guarantee success and too much overuse of humor could make lower effect (Teixeira and Stipp, 2013). Besides, humor can occur in various forms, types and have different communication objectives Speck (1991). All of them produce different effects of humor in advertisement. Using humor in advertisement could be a tricky issue and therefore requires a lot of attention. If humor does not pay off it could cause serious damages to the product or company image (Januz, 1977).

The literature is covering many aspects, but what is not covered is influence that humor has in advertisement and suitable products. All these parameters influence the effect of humor in modern advertisement. Therefore the aim of this research is to investigate humor approach in advertisements, the effect that humor creates in advertisement and test parameters which influence and have an impact on the final effect. On practical level, this research contributes to understand the effect of humor providing guidelines for its wide usage in today modern Advertising, contributes with experience supported by research findings and supplements for professionals in advertisement agencies with new empirical findings.

\section{Use of humor in advertisement}

In literature humor is frequently covered and explored topic in the last fifty years. A numerous authors find humor as a very inspiring theme for research. Hence, a significant number of them give different and broad approach to various kinds of humor dimensions. Back in the 70 s, according to Sternthal and Craig (1973) humor characteristics are:

1) Humorous attract attention,

2) A humor may increase liking for the source and create a positive mood,

3) Humorous may produce affect comprehension,

4) Humor may increase persuasion, distract the audience and reduce contra arguments in the message;

5) Humor tends to improve source credibility. 
6) Audience characteristics may confound the effect of humor.

Years later, according to Madden and Weinberger (1984), communication objectives of using humor in literature and those are: attention, comprehension, brand linkage, persuasion, action, and source credibility.

Execution of humor in advertisement could be observed by some factors divided in two groups. The first group is the relationship between humor and product or message. According to Speck (1990) there are three separate groups, intentional, structural and semantic relatedness. While, other group includes humor types: comic wit, sentimental humor, satire, sentimental comedy and full comedy. There is no one humor type that has universal positive or negative characteristics. Further Speck identifies five humor types:

1) Comic wit - incongruity resolution humor (level of respondent surprise);

2) Sentimental humor - arousal safety (the degree of effected relief);

3) Satire - incongruity resolution and dispositional humor (identification with or detachment from the humor's victim);

4) Sentimental comedy - incongruity resolution and arousal safety humor;

5) Full comedy - incongruity resolution, dispositional, and arousal safety humor.

There is a group of authors in reference literature focusing on observing audience response to humor. According to them humor may operate to get viewers response with two mechanisms: mechanism of attention and mechanism of affect (Cline et al., 2003). Humor produces both attention (cognitive mechanism) and mood (mechanism of affect) routes to memorability. Both attention and affect via a dual process mediate the impact of humor straight and its connection with the message. Affect has direct or indirect influence of recall, while attention has an indirect effect through affect and in creating recall. Even earlier, according to Maden and Winberger (1984), attention is necessary but not sufficient for effective message. While affect, as humor-related mechanism, is one which lead advertisements directly to the heart of the message and creates a positive impact. Humor itself does not directly affect the message importance. Thus, according to them the best humor-related objectives are in fact awareness and attention. In general, humor creates a positive mood and produces persuasion when exposed to an advertisement, beside cognitive response to humorous part, consumer could be distracted from processing important message information. This occurrence in practice is called "vampire effect" (Eisend, 2011). "Vampire effect" stands in literature to explain the effect when humor helps consumers to overcome weaknesses in message comprehension, but distract them from important information of the message. Therefore, in conclusion, there are three ways how humor can influence cognitive response in advertisement: First, humor produces cognition in general, whether positive or negative (information processing approach); second, humor reduces negative cognition (distraction effect); Third, humor produces cognitions in general but reduces the main message (vampire effect). 


\section{Effects of humor in advertisement}

Despite the earlier use of humor by advertisers, very little is known about the risks and the benefits of using humor Sternthal and Craig (1973). Having in mind effect of humor in advertisement, Sternthal and Craig, developed a number of propositions about the impact of humor in advertisement. Two of them are: (1) humorous messages attract attention, and (2) audience characteristics may confound the effect of humor. In contrast, according to Januz (1977), if humor in advertisement is not done and executed well it could only produce effect, instead it is done in bad taste or poorly it could be a disaster. Humor is more difficult to create (Maden and Weinberger, 1984). But, humor is more important in adverting then non-humorous appeal of advertisement message. Besides, the risk of using humor and its negative effect is very high, still humorous advertisement works better than non-humorous. However, experience tells that many advertisements which incorporate humor and intend to be funny do not succeeded in being perceived as humorous (Alden and Wayne, 1993). Generally, using humor in advertisement will have both, positive and negative effect.

According to Runyon (1979), two factors might be expected to influence the positive effect of humor. First, humor should be directly related to and well integrated with the objective and message of advertisement. Second, advertised product or service should be appropriate to be subject of a joke. According to Zinkhan and Johnson (1994) humor increases audience attentions, creates positive influence and positive overall emotion. Besides, humor may make advertisement funnier and more enjoyable and is obviously considered as guarantee for effective advertisements (Winberger, Spots, Cambel and Parson, 1995). According to Strick M. et al. (2009), humor produces positive effect in advertisement without changing or improving any brand information in advertisement. However humor present in advertisements attracts more consumers' attention and creates recall. Humor increases purchase in deed more often than any other forms of entertainment, while too much humor reduces purchase intent (Teixeira and Stipp, 2013).

Even though humor could sell and it occasionally does, there are some arguments against it. Early in the past, according to Phillips (1968), humor involved a risk. If it pays off then it's worth it. But if the used humor fails to pay off, then it is a disaster. The knowledge of humor effectiveness does not much evaluate since 1950s and 1960s when some advertisers voted against its usage (Madden and Weinberger, 1982). In contribution, according to Gelb and Pickett (1983), perceived humor had a negative impact on persuasion. Some studies latter find out that humor may distract viewer's' 'attention from brand and product information in the Advertisement, so called "vampire effect", which is arguably considered as main disadvantage of humorous advertisements (Weinberger et. al, 1995). Other group of authors observes that despite billions of dollars spent on advertisement it is not hard to observe that there are obviously some negative effects of using humor in advertisement (Flaherty, Weinberger, and Gulas, 2004). If humor is not recognized or is perceived as not funny it could cause serious negative effects to the advertised product. This is the case when humor is perceived as boring, offensive and reduces credibility. Humor sometimes does not pays-off. The failed humor is viewed as annoying, not useful, not entertaining and not original. These residual effects emphasize the downside risk of using humor in advertisement. In some cases 
as well, audience may not find humor in advertisement to be funny (Beard, 2008). Thus humor should be used carefully, because of the potential risk which could occur. Such risks are being too aggressive, risk of humor to be related with inappropriate theme, risk to be related with inappropriate product or simply being irritating and seen as irrelevant. Beside all of this, advertisements require significant amounts of money spending for developing and broadcasting funny TV advertisements but at the end consumers may find themselves asking: "Nice Ad, but what was the brand about? (Kuilenburg et al., 2011). The possible gap of using humor in advertisement is that people may focus on humor or joke presented in commercials so strongly that they would not go through the important information. According to Ackerman (2011), there are several critics about humor in advertisement. One is that leading humor its hart to do it! What seems funny for ones is just not funny enough for others. The second critic is that fun has a short shelf life and it has to be replaced very often. Even the funniest interesting laughing joke is only interesting once. Over time, the more the viewers are exposed to it, the less interesting it is. The third and biggest issue refers to the appeal to emotion. Sounds little ironic and paradoxical but tears work better than humor in entertainment

Hence, having in consideration all known positive and negative effects of humor in literature, humorous advertisements are divided into two general categories (Kuilenburg et al., 2011). First categories are advertisements with low-complex humor that either may or may not be related with the brand. They include those advertisements with one humor process. These advertisements could attract consumer attention, positively affect the viewers' mood but beside that they could not create effect on brand. Second group is formulating by advertisements with high-complex humor such as complex-humor containing all three humor processes. These advertisements are further divided into two separate groups: high-complex humor but not related with the brand and high-complex humor related with the brand. The first group consists of advertisements with same advantage but those advantages are overshadowed by the negative effects of humor. Those are advertisements with problematic use of humor. The humor can attract a lot viewer's' attention but could distract their attention from the most important characteristic, brand name - the 'vampire effect' (Weinberger et. all 1995). Second group are advertisements with high-complex humor which is related to the brand name. Those advertisements have strong assets, create positive advantages but also create brand relation. Humor attracts viewers' attention thereby directing it towards the brand name.

\section{Product types and relatedness with humor in advertisement}

According to Weinberger and Campbell (1991), humor effect is observed by two parameters, humor relatedness and humor complexity. When humor is used in advertisement it can be related or not related with the product or brand name. Related humor is humor linked to the advertised product. Humor straight in general refers to how funny an advertisement is rather than referring to whether or not an advertisement includes humor (Elpers, Mukherjee, and Hoyer, 2004). In terms of complexity, high complex humor pays more attention to humorous parts of an advertisement. While, low-complex humor does not much affect the audience, no matter whether it is related or not related with the brand. Related humor draws 
viewers' attention quickly and audience focus would be on the advertised brand. On the other hand, when humor has not clear relation with the brand then viewers' attention would be more on humorous part and not on the brand name (Kuilenburg, Jong. and Rompay, 2011). Positive effect is created when humor is related and well integrated with the object or message in the Advertisement (Klein, Bryant, and Zillmann, 1982), while not related humor will have either no impact or negative impact (Scott, Klein and Bryant, 1990). In literature there are varieties of opinions. Thus humor attention or humor strength is translated into positive effect as long as it is linked with the product. And in opposite, un-related humor, not related to the product, could actually inhibit product recall. All this recall is the funny part of the message which entertains with no higher effect (Cline and Kellaris, 2007). According to Speck $(1987,1991)$, humor relatedness with the product has more specific description. Hence, whether or not humor is related to message Speck, identifies three categories:

Intentional relatedness, relationship of humor to message type and message processing. Those are:

1) Humor dominant: Product message is presented with a humorous content in the ad. If the humor is removed, the advertisement does not make sense.

2) Message dominant. There are two separate types

a. Information-focused: Humor in the advertisement is semantic, contains message arguments and requires a different processing style than that in humor dominant advertisements. If the humor is removed, the advertisement still makes sense.

b. Image-focused: Humor in the advertisement is visual and closely related to the product and/or user. However, if the humor is removed, the advertisement still makes sense.

Semantic (thematic) relatedness, the relationship of humor to product related theme in advertisement. It gives more explanation of humor relatedness with product, its use, its name or its benefits.

Structural relatedness, syntactical function of humor with in message-dominant advertisement and product information with humor-dominant advertisement; At humor-dominant advertisement, structural relatedness is so intense that quite often it is confused with thematic relatedness, while with message-dominant the distinction between them is clear. Also, according to Speck (1991), nearly two thirds or $65 \%$ of the advertisements were humor- dominant, less with $20 \%$ is information-dominant and around $20 \%$ were image-dominant. While, according to Beard (2005), through the years when advertisement practitioners refer to the issue whether the humor is relevant or irrelevant, they usually refer to the thematic relatedness. While, Speck (1991) notes that thematically unrelated or irrelevant humor in practice is very rare, but in cases when it happened, it is found in advertisement of local cars, furniture or appliance advertisement.

The Product Color Matrix uses colors to highlight the meaning of the products Weinberger et al. (1995). Using the Product Color, Matrix, the products are divided according their characteristics into four different groups, White, Red, Blue and Yellow. According to these 
classification and product characteristics, Weinberger and his colleagues analyze the effect of humor usage in advertisement and whether or not the product advertised is suitable for humor.

Table 1. Different product types according Color Matrix

\begin{tabular}{c|l|l|}
\multicolumn{1}{c}{ Product base on Rational site } & \multicolumn{2}{c}{ Products base on Emotional site } \\
\cline { 2 - 3 } $\begin{array}{c}\text { High } \\
\text { Involvement } \\
\text { products }\end{array}$ & $\begin{array}{l}\text { Cars, Home, Major applicants, } \\
\text { consumer electronics, Insurance } \\
\text { products and many non-routine } \\
\text { business products }\end{array}$ & $\begin{array}{l}\text { Sport cars, Jewelry, Cosmetic, } \\
\text { Fashion apparel and other products } \\
\text { representing Individuality }\end{array}$ \\
\cline { 2 - 3 } $\begin{array}{c}\text { Involvement } \\
\text { products }\end{array}$ & $\begin{array}{l}\text { Household products, Laundry } \\
\text { products, Personal care products, }\end{array}$ & $\begin{array}{l}\text { Beer, Chips, Gym, Candy, Soft } \\
\text { drinks, Wine, Cigarettes and other } \\
\text { everyday routine products }\end{array}$ \\
\cline { 2 - 3 }
\end{tabular}

Source: developed by authors according to article Weinberger et al., (1995),"The use and effect of humor in different advertisement media" Journal of Advertisement Research, 35(3), p44-56.

Hence, white products are high risk products often, not always, based on price. Those are "Big" tools products which often fill functional need, ex. refrigerator, washers/dryers machine and other such appliances products. They are durable, expensive products and regarding consumer shop they involve risk with the choice. Among them are also automobiles, other products as insurance, and many non-routine business products. (see table 1) Red products. Red color is chosen for those products because it symbolizes grandiosity and expressivity. Those are products like sport cars, the red dress, fancy tie, jewelry, and other of those product types representing individual and high risk red products. Red are "Big toys" products and are high in motivation process. They are gaining high focus attention on the advertisement and have semantic processing style (see table 1). Blue products, represent low-risk are functional-decision making products. Products in this group are also call "Little" or small tools which are consumption and help in accomplishing small tasks. Blue products are non-durable products. They are products with low product risk, functional, such, cleaning, cooking products, personal hygienic products etc. For instance blue is toilet blower cleaner, the laundry detergent, mouthwash which all is part of the set of routine products. Certainly there are many products which are not physically blue but share the same characteristics. Staple food items, many health and beauty products over-the-country drugs are all in same category. Yellow goods or "Little" toys are seen as day-to-day reward products which we often threat ourselves with. Snack chips or Beer are most color representative products in this category, but the group is much bigger including: gym, candy, soft drinks, wine and cigarettes. These products are low-risk routine purchases which make us feel little better focusing on satisfaction and expressiveness. Compared with Red "toys", Yellow "toys" are not that risky. These products are low in motivation to process, low focus attention on advertisement and heuristic processing style vs. systematic characterized for Red products. (see table 1). Thus, several authors in literature have done their conclusion about most suitable products and their risk of using humor. According to Kelly and Solomon (1975), for white products are most 
appropriate either information or image focused humor while for yellow products should only be image-dominance. Humor as effective tool to attract consumers' attention has huge use in commercials for food and beverage industries as well household goods. While others, consider using humor in advertisement as every day practice for all products (Gulas and Weinberger, 2006, Szymańska-Waczyńska, 2013). They conclude that the level of risk is crucial and has to be considered when deciding to use humor in advertisement. Low risk yellow products "little toys" and blue products can be effectively advertised with humor, whereas humor is less suited with high (red) emotional and high risk (white) functional products. In addition, it appears that yellow goods are most suited to humor, while red goods are the least suited. Furthermore, white and red high risk products have the lowest levels of humor usage and humor is less suited to these products.

According to Madden and Weinberger (1984), humor is more appropriate for some products. In general, consumer nondurables and business services were seen as most congruent with the use of humor, whereas corporate advertisement and industrial business products were viewed as least suited for use of humor. Also most suited products for humor are food, soft drinks and alcohol products, while less suited are health and beauty aids. In other study, most frequently mentioned products best suited for humor were soft drinks, food, alcohol, snacks, candy, restaurants, health, beauty, toys, and games in that order Rehman and Brooks (1987). Less appropriate products to use humor are also personal and famine hygiene products, alcohol, contraceptive and pregnancy tests and drugs for terminal illness. Only $10 \%$ of advertisement with durable products uses humor in contrast with high $40 \%$ of non-durable product advertisement which use humor (Stewart and Furse, 1986). Furtherer, results show that humor advertisements has more success at existing products then the new products. Another potential factor is the nature of the product. advertisement executives believe that low-involvement products such as non-durable products (as, wine, snack food, beer etc.) are best suitable for using humor in advertisement (Weinberger et al., 1995, Toncar, 2001), while high-involvement durable products such as, perfumes, fashion clothes are less suitable for use of humor. Services which include abortion, sterilization, mental illness treatment, calming care, funeral direction and artificial insemination (Miller and Waller, 2004). However humor is not such a strong tool for advertisement in industries that rally on trust or technological achievements, as companies in the financial, telecommunications and electronics sector (Dong-Hun 2009).

\section{Research Methodology}

For the purpose of investigating the effects of humor in modern advertising, several factors were taken into consideration, as humor type, relatedness with the message and different products which are suitable for humor usage. According to Weinberger and Gulas (1992), those relationships can intervene between given humor and its outcome. Therefore, accordingly, there are dozens of probable relationships between variables and possible divergent effects. Hence, broad generalizations about effects of humor in advertisement are inappropriate. Therefore, the effect of humor in advertisement may be observed by two parameters, humor relatedness and humor complexity. Those are important parameters for measuring effect, but interaction between them is much more important than their separate 
effect.

The main research aim with this project is to investigate the humor approach in advertisements, the effect which humor creates among audience and the way it is perceived. Therefore, following objectives could be identified:

1) To investigate the meaning of the humor used in advertisement and to investigate whether humor in modern advertisement is more effective than serous version of message appeal;

2) To find out parameters used to produce higher effectiveness: humor complexity and relatedness of humor with the product advertised and their correlation in between;

3) To find out appropriate products for use of humor in advertisement;

The envisioned research process combined with the enthusiasm to meet the already defined objectives includes two independent surveys:

First survey is an Interview process. The Interview process was held with some prominent professionals and experts with a long professional experience in marketing and advertisement. The group also includes marketing executives. This group of prominent professionals can contribute to this research with their expertise, professional experience and long-lasting practice and involvement in Marketing. Second part of this research process is online survey. The questionnaire is distributed to two groups in two different ways. The first group consists of young high educated people, students. They are representing young population and the assumption is that they are with high sense of humor and are frequently exposed to use of humor on a daily basis. Second group are social network people between age 20-50, travelers, from different nationalities, willing to travel the world and have adventure spirit. The questionnaire is structured in two main groups of questions. First group is questions arising from the advertisements they have watched at the very beginning. Those are questions upon each advertisement separately and contain personal impression of participants after watching the advertisement. The questions are same for the two different advertisements. The reason in behind is that researcher intends to receive different perspective from the respondents after watching different type of humorous advertisements. What is even more important here is that the researcher wants to check if the respondent remembers the main message in the advertisement, what type of reaction the Ad produces and which elements caught viewers' eye. After the participants answer the first group of questions they proceed with the second group of questions titled as Personal questions. This is a group of questions referring to respondent point of view of humor in general and the way he/she perceives the humor in advertisement. Those questions as well have strong reason in behind. The researcher wants to discover point of humor, sense of humor and need for humor of respondents. This is an important variable which influences the effect of humor used in advertisement. Further on, the research wants to catch respondents preference of humor message and humor used in advertisements. As well, respondents give personal point of view for suitable product and media for use of humor in advertisement.

Advertisements included in this survey will be carefully chosen. There are two major criteria based on which advertisements are chosen. Main criteria are parameters which have an 
impact on humor effect in advertisement, humor complexity and humor relatedness. Hence, both advertisements include humor but the difference is type of used humor. The researcher wants to receive different impression from different advertisements base on the same questions. One of the advertisements uses thematic, related high-complex humor strongly related with advertised product and brand. This advertisement is placed second in the survey. The first advertisement uses complex humor but not related with the advertised product. This kind of advertisements is what usually makes people laugh and therefore is placed at the very beginning of this survey to make the audience feel relaxed, to attract their attention and give them laugh as they expected. Other important selection criterion is the ratings, popularity or awards which those Advertisements received. According to Gulas and Winberger (2006, p.19), "biggest world Advertisement TV channel for airing funny commercials today is Super Bowl". The day in which the Super Bowl is played is considered by some as a national holiday, second-largest day in the U.S. for food consumption (Belkin, 2004). Super Bowl has frequently been the most-watched American television broadcasting of the year and most-watched American television program in history with an average audience of 111.5million viewers (Koba, 2014). Hence many high-profile television advertisements are broadcast during the game often coming from major brands (such as Budweiser, Clydesdales, Doritos, Pepsi etc.) among lesser-known brands seeking exposure. As a result, watching and discussing Super Bowl Ad has become a significant aspect of the event. Super Bowl advertisements have become cultural phenomena of their own; many viewers watch the game to see the commercial, while many national surveys judge which advertisement carries the best viewer response (Siltanen, 2014).

Second important criterion included in this project is The International Festival of Creativity in Cannes, France, where every year the best advertisement achievements and results are awarded. Cannes Lions is the world's biggest celebration of creativity in communication. It is a home of great ideas changing the way brands interact with their consumers. "Every time I come, I leave as a much bigger person in terms of my understanding of creativity" Jonathan Midenhall, Marketing communication and design excellence for North America of the Coca-Cola Company (Mildenhall J.). The Guardian names it as an annual event that commonly attracts thousands of delegates from around the world to attend the world biggest Ad festival (Sweney, 2010). Hence, this festival is considered as the largest gathering of worldwide advertisement professionals, designers, digital innovators and marketers (Chamikutty, 2010). "What happens in Cannes ultimately is a reflection of what happens in the business, said festival executive chairman Terry Savage (AdWeek 2007).

\section{Advertisement 1:}

First Advertisement chosen for this research is titled: "Hello Stranger" Budweiser Beer advertisement "A woman at home calls her guy at the office and in a suggestive voice says, "Hi, let's play the Stranger". Intrigued, the man at his desk agrees. She continues: "When someone gets home tonight, someone will be wearing a naughty French maid's outfit, blonde wig and holding a six pack of Bud Light" Thrilled he says, "ME like the Stranger". Later, the doorbell rings and she opens the door, she sees "her" beau has misunderstood her plan - he's the one wearing the outfit, both surprised and he says: "Oh! You meant..." She closes the 
door in his face. A moment later, an old man opens the door open and says: "Well hello stranger!" - Anon, ArRespect [online]

\section{Advertisement 2}

One of the best Advertisements ever and second one in this research is Lion winner on International Festival of Creativity in Cannes, France, "The power of dreams" Honda Accord advertisement, which is also named as five top UK Advertisements for all time. "The commercial begins with a tiny cog rolling slowly along the ground and setting off an elaborate chain reaction that culminates in the production if a gleaming Honda Accord. One, by one, the bits of rubber, plastic and metal that make up the car collide with each other - a windscreen wiper flies into the air, gently knocking a tin of engine oil that topples over to lubricate a set of ball bearings. The Ad ends with a brand new Honda Accord rolling of a steal seesaw." (Anon, 2003)

\section{Discussion}

\section{Is humor better option than serious version of the message?}

Results from the survey, according Table 1 confirm that people find humorous version more effective than serious version of message appeal.

Table 1. The effect of message appeal

\begin{tabular}{|r|c|}
\hline Serious version of the message appeal & 40 \\
\hline Humorous version of transmitting the nmessage & 86 \\
\hline Other version of appeal (fear, sex, emotion..) & 62 \\
\hline
\end{tabular}

While, according to the table 2 and table 3, majority of survey's participants agreed that the use of humor depends on the product advertised and does not always guarantee success.

Table 2. People enjoy watching humor in Advertisements

\begin{tabular}{|r|r|}
\hline Ad without humor is not an Ad & 40 \\
\hline depends of the product advertised & 156 \\
\hline no, I don't enjoy watching humor in Ad. & 4 \\
\hline
\end{tabular}

Therefore, two different advertisements are tested with the same audience in order to be scan different effects.

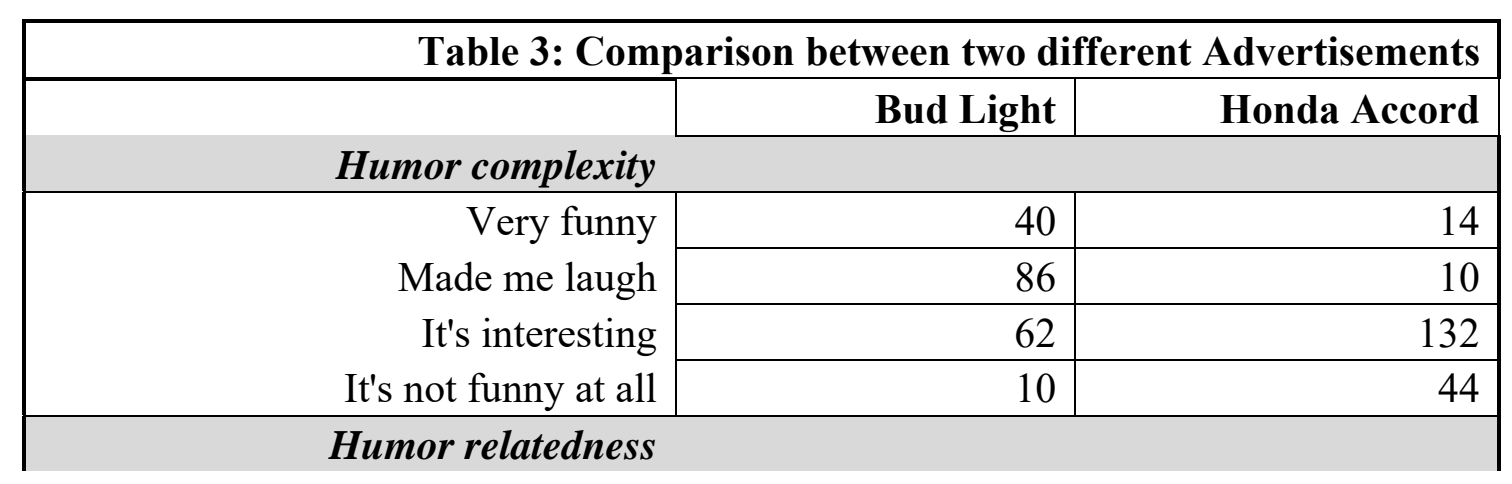




\begin{tabular}{|c|c|c|}
\hline \multirow{3}{*}{$\begin{array}{r}\text { Humor is strongly related } \\
\text { Humor is not related } \\
\text { I don't find humor }\end{array}$} & 84 & 84 \\
\hline & 108 & 26 \\
\hline & 6 & 90 \\
\hline Which Ad people liked more? & 105 & 95 \\
\hline Which AD creates better effect? & 94 & 100 \\
\hline \multicolumn{3}{|l|}{$\begin{array}{r}\text { Do you remember the message of } \\
\text { the ad? }\end{array}$} \\
\hline yes & 10 & 46 \\
\hline I think was, but I am not $100 \%$ sure & 28 & 38 \\
\hline $\begin{array}{r}\text { No, I am sorry I haven't remembered } \\
\text { it. }\end{array}$ & 162 & 116 \\
\hline \multicolumn{3}{|l|}{ Main focus in advertisements: } \\
\hline the joke & 106 & 4 \\
\hline the message idea & 32 & 66 \\
\hline the story & 40 & 98 \\
\hline the product advertised & 16 & 24 \\
\hline other & 4 & 8 \\
\hline \multicolumn{3}{|l|}{$\begin{array}{r}\text { Would you switch to use the product } \\
\text { after watching the ad? }\end{array}$} \\
\hline Definitely, I liked the ad. & 36 & 30 \\
\hline $\begin{array}{r}\text { I like the ad, but I will continue to } \\
\text { use my trusted brand }\end{array}$ & 140 & 150 \\
\hline I am already using this brand & 24 & 20 \\
\hline
\end{tabular}

People found Bud Light Ad funnier, while in general they found Honda Ad interesting. According to them, both advertisements create same effect among audience and there is no winner. But, it is interesting to note that half of the Honda voters said the Ad creates effect because there is stronger message behind the story. While, Bud Light voters' consider is effective because it's funnier. Most of the experts agree that humor is a preferable and required option in advertisements, but it depends on many factors, including audience, product, service, available budget etc. The experts consider humor as a very powerful emotion and are a good option to be used if appropriate with the object. Hence, there are worries and concerns - whenever the advertisement is heard, seen and leaves emotional impression when heard for the first time, the question arising is whether it would produce the same effect afterwards. Media Director has considers humor as a risky approach since certain people tend to get offended if they feel the joke is not effective. Therefore, humor needs to fit the overall brand image, values, look and feel. Experts are also on the same line with purchase intention of humor. "Humor cannot produce purchase intention, as the purchase intention depends on product benefits, whether or not product meets costumer needs, desires or wishes". Thus, one major component that improves humor positive effect is mechanism of attention. Attention is regarded as necessary but not sufficient for effective message. Regarding the question "Is the application of humor worth the money spent for its creation? 
Experts provide a wide range of answers. $60 \%$ of the time is cost-effective, while, Executive Marketing director points - good advertisement always worth for the money spent, "if targets are high and budget is tight, I would always go for humor in advertisement". When they were asked if they personally prefer to use more humor instead of serous advertisement they agree that humorous and original approaches are more preferred. Most of the time emotional appeal is used, never less than humor or empathy. "When you touch the heart, the mind will follow, but it depends on the tone of communication, whether it is appropriate to use humor".

\section{Effects which humor creates in advertisements}

After testing the effects of humor, it could be concluded that despite people like the humor and enjoy watching it in advertisements, still humor can keep their attention watching it till the end but it does not create purchase in habits neither sells recall. In addition, too much humor could produce opposite effect and could not even capture the audience attention. Instead it could only make the audience laugh, but the only thing they will remember is the joke itself and not even the product or message advertised. Bud Light Ad is a good example for that. While nearly half of participants of Honda Ad remember the message, even half of this half could exactly write it down. Despite the fact that half of Honda viewers consider this advertisement as not humorous, they still kept their focus on the story and message idea. While, regardless of whether the advertisements keep audience attention or just entertain the audience, the results showed that humor does not intend purchase re-call. People continue to use their trusted brand and despite the fact they liked the advertisements they won't switch to this advertised brand. Majority of experts agreed that humor works best in gaining attention and create persuasive effect. Several effects of humor can make advertisement more memorable as leavening long-term positive feeling with the customer after seeing them. Other one is word-of-mouth effect which letter becomes "talk" of town. Humor has potential to throw people off balance, inspiring certain behavior and excited target audience regarding some objectives. Humor has downside as well - can distract the attention from the product or advertised brand. Using humor in advertisement does not always pay-off. In some cases or industries it is even better to be avoided because it could offend the audience. Wide use of humor lately positively influences audience, but is not sufficient and does not guarantee success. Despite its usage, it is hard to be measured even nowadays.

\section{Appropriate products for use of humor in advertisement}

Following the results of this survey (table 4), yellow products are most suitable and mostly used for humor as, beer, soft drinks, followed by low risk (blue) functional products, such as household products. While, humor is less suitable for high (red) emotional products as life insurance or brand clothing and in comparison more suitable for white functional products, like sport cars, but far more behind the yellow or blue product. For the humor to create effect it must be related with the product or brand Advertised, stated almost all experts. Humor to be successful must be related with the product. Positive effect is created when humor is well integrated with the object or message in advertisement, while not related humor will have either no impact or negative impact. While experts highlight as more suitable product, entertainment TV shows, alcohol beverage, mobile telephony, internet, public awareness 
campaigns for waste management. They even include serous products, such as bank products (credits, deposits), states Marketing executive from Bank sector. While products not suitable for humor usage are medical or health care products, as well services regarding finance and security. "People tend to respond badly to jokes regarding things they find important to their own well-being as well as to the welfare of their family".

Table 4. appropriate product for humor usage

\begin{tabular}{|r|r|}
\hline \multicolumn{2}{|c|}{} \\
\hline Beer & 86 \\
\hline Soft drink & 28 \\
\hline Life insurance & 12 \\
\hline Clothing & 8 \\
\hline Household product & 18 \\
\hline Sport cars & 22 \\
\hline Other & 26 \\
\hline
\end{tabular}

\section{Conclusion}

Generally, people like the humor and want to watch on TV show, in every-day life, everywhere, regardless of age, culture and gender. If only humor is suitable and created with sense, good taste and carefully considering all aspects it is a powerful instrument in an advertisement. Humor used in advertising positively affects attention paid to advertisement, linkage of advertisement, reduces irritation experience and increases linkage and attachment to the product. Humor increases audience attentions, creates positive influence and positive overall emotion. Besides, humor may make advertisement funnier and enjoyable and is obviously considered as a guarantee for effective advertisements. But, humor also involves a risk. If it pays off then it's worth it. If used humor does not pay off then it might be detrimental. Positive effect is created when humor is related and well integrated with the object or message in advertisement.

There are three ways how humor can influence response: humor produces cognition in general, whether positive or negative, then, humor reduces negative cognition and last, humor produces cognitions in general but reduces the main message (vampire effect).

In summary, the following conclusion about humor can be inferred:

1) People find humorous message more effective than serious version of the message.

2) Humor attracts attention, may increase liking for the source and create a positive mood.

3) Humor makes advertisement more memorable and leaves long-term positive feeling inside the customer after seeing them.

4) Humor has word-of-mouth effect and easily becomes "talk" in town.

5) $60 \%$ of the time humor is cost-effective. 
6) There is no humor type that has universal positive or negative characteristics.

7) The anomaly of humor in advertising is that effectiveness of the humor is hard to measure even nowadays.

The use of humor depends on the product advertised and does not always guarantee success. Humor must be related with the product advertised and be attached with appropriate one. Humor has been widely used for food and beverages, household goods as affective tool to attract audience attention. However, humor has not been widely used by companies which require buying decisions based on trust and technology prowess, as companies in finance, telecommunication and electronic industries. Best suited products for humor include soft drinks, food, alcohol, snacks, candy, restaurants, health, beauty, toys, and games.

\section{References}

Ackerman, J. (2011). Funny is money?. The Enterprise, 13-19.

Alden D., Hoyer W., \& Lee C. (1993). Identifying global and culture-specific dimensions of humor in advertisement: A multinational analysis. Journal of marketing, 57, 64-75. http://dx.doi.org/10.2307/1252027

Alden, D. L., \& Hoyer, W. D. (1993). An examination of cognitive factors related to humorousness in television advertising. Journal of advertising, 22(2), 29-37. http://dx.doi.org/10.1080/00913367.1993.10673401

Beard, F. K. (2005). One hundred years of humor in American advertisement. Journal of macro marketing, 25(1), 54-65. http://dx.doi.org/10.1177/0276146705274965

Beard, F.K. (2008). Advertisement and audience offense: The Role of intentional humor. Journal of Marketing Communications, 14(1), 1-17. http://dx.doi.org/10.1080/13527260701467760

Belkin, D. (2004, January 29). Super Bowl underscores cultural divide. E-journal of The Boston globe.

Berger, A. A. (1987). Humor: An introduction. American behavioral scientist, 30(1), 6-16. http://dx.doi.org/10.1177/000276487030003002

Chamikutty, P. (2010, June 9). World's biggest ad festival to kick off in Cannes. E-journal of The Times of India.

Cline, T. W., Altsech, M. B., \& Kellaris J. J. (2003). When does humor enhances or inhibits AD responses?: The moderating role of the need of humor. Journal of Advertisement, 32(3), 31-45. http://dx.doi.org/10.1080/00913367.2003.10639134

Cline, T., \& Kellaris, J. (2007). The Influence of humor strength and humor-message relatedness on Ad memorability: A dual process model. Journal of advertisement, 36(1),

Eisend, M. (2011). How humor in advertisement works: A meta-analytic test. Marketing letters, 22(2), 115-132. http://dx.doi.org/10.1007/s11002-010-9116-z 
Elpers, J., Ashesh, M., \& Wayne, H. (2004). Humor in television advertisement: A moment-to-moment analysis. Journal of consumer research, 1(3), 592-598. http://dx.doi.org/10.1086/425094

Flaherty, K., Weinberger, M. G., \& Gulas, C. S. (2004). The Impact of perceived humor, product type, and humor style in radio advertising. Journal of current issues \& research in advertising (CTC Press), 26(1), 25-36. http://dx.doi.org/10.1080/10641734.2004.10505154

Gelb, B. D., \& Pickett, C. M. (1983). Attitude-toward-the-ad: Links to humor and to advertising effectiveness. Journal of advertising, 12(2), 34-42. http://dx.doi.org/10.1080/00913367.1983.10672838

Gulas, Ch. S., \& Weinberger, M. G. (2006). Humor in Advertisement: A Comprehensive Analysis. M. E. Sharpe.

Januz, L. R. (1977). Humor in advertisement can be effective if used carefully and with good taste. In Inland Printer, American Lithographer (p.70). University of Michigan Library. Maclean-Hunter Publishing Company.

Kelly, P. J., \& Solomon, P. J. (1975). Humor in television advertisement. Journal of advertisement, 4(3), 31-35. http://dx.doi.org/10.1080/00913367.1975.10672594

Klein, D.M., Bryant, J., \& Zillmann, D. (1982). Relationship between humor in introductory textbooks and students' evaluation of the texts' appeal and effectiveness. Psychological Reports, 50, 235-241. http://dx.doi.org/10.2466/pr0.1982.50.1.235

Koba M. (2014 January 28). Super Bowl TV ratings: Fast facts at a glance, Cnbc.com.

Lee, D. (2009). Six trends in advertising: analysis of successful TV commercials. SERI Quarterly, 2(3), 103-109.

Madden, T. J., \& Weinberger, M. G. (1984). Humor in advertising: A practitioner view. Journal of advertising research, 24(4), 23-29.

Madden, T.J., \& Weinberger, M. G. (1982). The effect of humor on attention in magazine advertisement. Journal of advertisement, $11(3), \quad 8-14$. http://dx.doi.org/10.1080/00913367.1982.10672806

Mildenhall J. (2014). Cannes Lions, official website. Retrieved from: https://www.canneslions.com/about_us/

Miller, K. E., \& Waller, D. S. (2004). Attitudes towards DTC advertising in Australia: An exploratory study. International journal of advertising, 23(3), 389-405.

Phillips, K. (1968). When a funny commercial is good. It's Great!. Broadcasting, 74, 26.

Rehman, S. N., \& Brooks Jr., J. R. (1987). Attitudes toward television advertisements for controversial products. Journal of health care marketing, 7(3), 78-83.

Runyon, K. E (1979). Advertisement. In Charles E. (Ed.), Advertisement and the practice of marketing (pp.246). Columbus, OH, Merrill Publishing Co. 
Scott, C., Klein, D. M., \& Bryant, J. (1990). Consumer response to humor in advertising: A series of field studies using behavioral observation. Journal of consumer research, 16(4), 498-501. http://dx.doi.org/10.1086/209235

Siltanen, R. (2014, January 29). Yes, A Super Bowl ad really is worth \$4 million. E-journal of Forbes.

Speck, P. S. (1990). The humorous message taxonomy: A framework for the study of humorous ads. Current issues \& research in advertising, 13(1), 1.

Speck, Paul Surgi (1987). On Humor and Humor in Advertisement, Unpublished Doctoral Dissertation, Texas Tech University.

Sternthal, B., \& Craig, C. S. (1973). Humor in Advertising. Journal of marketing, 37(4), 12-18. http://dx.doi.org/10.2307/1250353

Stewart D.W. \& Furse D.H. (1986). Effective Television Advertisement: A study of 1000 Commercials. Lexington Books.

Strick, M., van Baaren, R., Holland, R.W., \& van Knippenberg, A. (2009). Why humor breaks resistance to influence: Implicit effects of distraction and positive affect. Advances in Consumer Research, 36, 1015.

Sweney, M. (2010, June 22). Sir Martin Sorrell: Cannes Lions is 'a chance to get away. E-journal of The Guardian (London).

Szymańska-Waczyńska, B. (2013). Humorous celebrities endorsing high risk products: A review of current knowledge and research gaps. International journal of management cases, 15(2), 46-58.

Teixeira, T. S., \& Stipp, H. (2013). What's so funny about tracking reactions to humor?. Journal of advertising research, 53(3), 286-296. http://dx.doi.org/10.2501/JAR-53-3-286-296

The new Honda Accord - isn't it nice when things just... work?. (2003, May 9). E-journal of The Guardian.

Toncar, M. F. (2001). The use of humour in television advertising: Revisiting the US-UK comparison. International journal of advertising, 20(4), 521-539.

van Kuilenburg, P., de Jong, M. D., \& van Rompay, T. J. (2011). That was funny, but what was the brand again?. International journal of advertising, 30(5), 795-814. http://dx.doi.org/10.2501/IJA-30-5-795-814

Weinberger, M. G., \& Campbell, L. (1990). The use and impact of humor in radio advertising. Journal of advertising research, 30(6), 44-52.

Weinberger, M. G., Spotts, H., Campbell, L., \& Parsons, A. L. (1995). The use and effect of humor in different advertising media. Journal of advertising research, 35(3), 44-56.

Weinberger, M., \& Gula, C. (1992). The impact of humor in advertising: A review. Journal of advertising, 21(4), 35. http://dx.doi.org/10.1080/00913367.1992.10673384 


\section{Copyright Disclaimer}

Copyright for this article is retained by the author(s), with first publication rights granted to the journal.

This is an open-access article distributed under the terms and conditions of the Creative Commons Attribution license (http://creativecommons.org/licenses/by/3.0/). 